\title{
Business Education and National Development: Issues and Challenges
}

\author{
Christopher C. Ugwuogo
}

\author{
School of Business Education \\ Federal College of Education (Technical) \\ Umunze, Anambra State, Nigeria
}

Doi:10.5901/jesr.2013.v3n4p129

\begin{abstract}
This paper examined the role of education in general and business education in particular in national development. Education is considered as social instrument for developing human resources and for human capital formation. On the other hand, development is seen as a purposeful change in a society that contributes to social and economic well being and advancement of its people without creating any disharmony. Through literature, the paper established a significant relationship between education and development. It is in line with this that the role of business education, as a vocational discipline was discussed. Some factors that impede maximum contribution of business education to national development were highlighted. Finally, some recommendations were made among which is a call to do away with obsolete technologies.
\end{abstract}

\section{Introduction}

The term 'education' has been defined in various ways by various authors; some in a broad sense and others in narrow sense. Also different educationists have explained it according to the need of the time. Etymologically, the word 'education' according to Parankimalil (2012) has been derived from latin words:

$>$ 'educere' which means 'to bring out' or 'to nourish'.

$>$ 'educare' which means 'to lead out' or 'to draw out'.

$>$ 'educatum' which means 'act of teaching' or 'training'.

$>$ 'educatus' which means 'to bring up, rear, educate'

Beyond this account of the origin, the word 'education' has since assumed a wider definition and meaning. Education in a broad sense is a process by which an individual acquires the many physical and social capabilities demanded by the society in which he/she is born into to function (Uwadia, 2010). Similarly, Parankimalil (2012) sees education as a systematic process through which a child or an adult acquires knowledge, experience, skill and sound attitude. It is concerned with the development of all faculties of the child. It performs the functions of the physical, mental, aesthetic, moral, economical and spiritual development of the individual so that the individual may get rid of his animal instincts by sublimating the same so that he becomes a civilized person. Little wonder then that John Lock said "plants are developed by civilization and men by education". According to UNESCO study cited in Parankimmalil (2012), the fundamental aim of education is the physical, intellectual, emotional and ethical integration of the individual as a social instrument for developing human resources and for human capital formation. It is considered as the most important factor for development as well as for empowering people. 
The BusinessDictionary.com (2010) explains education as the wealth of knowledge acquired by an individual after studying particular subject matters or experiencing life lessons that provides an understanding of something. It goes further to say that the most common forms of education incorporates studies of a variety of subjects. This implies that education comprises different disciplines ranging from general education, agriculture, medicine, engineering, business education and others. This paper focuses on development as a product of education and the role of education in general and business education in particular in national development.

\section{Concept of Development: Nigeria in Perspective}

Development is a complex issue, with many different and sometimes contentious definitions. From a general perspective, development means a progression from a simpler or lower to a more advanced, mature, or complex form or stage. It is also defined as the gradual advancement or growth through a series of progressive changes. A basic perspective equates development with economic growth. It is from this perspective that United Nations Development Project (UNDP) in Development Workers in Global Solidarity (2010) defines development as to lead long and healthy lives, to be knowledgeable, to have access to the resources needed for a decent standard of living and to be able to participate in the life of the community.

Development is also seen as a purposeful change in a society that contributes to social and economic well being and advancement of its people without creating any disharmony (UNESCO, 2009). Development is a dynamic process. It empowers people and promotes important changes in their lives. From purely economic perspective, development brings about improvement in human welfare, quality in life and social well being. It is about satisfying the population's needs and wants. Development is measured using a range of economic indicators such as:

$>$ Gross Domestic Product (GDP): This is the total value of goods and services, produced in a country (US\$)

$>$ Gross National Product (GNP): Total value of goods and services produced in a country, including income from investment abroad (US\$)

> Purchasing Power Parity: Takes into account local cost of living and is usually expressed per capita (US\$)

Apart from economic indicators, there are other social indicators which are linked to the economy that are used to measure development such as literacy rate, pollution level, number in higher education, energy consumption, mortality rate, life expectancy, environment, politics, technological advancement and rate of industrialization etc.

In development rating, Nigeria is classified as a developing nation. With a GDP per capita of $\$ 2,700$ (2012 estimate), population below poverty line of $45 \%$ (2010 estimate) and unemployment rate of 24\% (2011 estimate) Nigeria was ranked 151 out of 185 countries in the United Nations Development Index in 2004 (Wikipedia, 2012). According to the same report, Nigeria's human capital is underdeveloped. The latest value of Human Development Index shows that Nigeria is ranked 156 among 187 countries. The economy is highly inefficient; the services and agricultural sectors account for 32 and 30 percent of employment respectively while manufacturing sector accounts for only 11 percent (Wikipedia, 2012).

The poor showing of Nigeria in development rating is not unconnected with the underdevelopment of her human capital since human capital development is linked to general development - economic, political or social. It then becomes imperative to look at the relationship between education and development.

\section{Relationship of Education and Development}

Development empowers people and promotes important changes in their lives. However, development cannot take place by itself. It requires an educated, skilled and competent people. 
Seen from this angle, education becomes the most important factor for development as well as for empowering people.

During the early 1960s a startling reversal of development theory took place. More intensive studies of economic growth revealed that only a part of it could be explained by the amount of capital investment. Other factors seemed to be at least as important in development. One correlation that loomed large in the studies by economists at this time was that between the level of education and economic growth. Some found a close relationship between elementary education and GNP; others maintained that higher education was the decisive factor; still others argued that literacy was the important element. Assuming that the level of education bore a causal relationship to economic growth, economists see "investment in human resources" as the essential condition for economic development (Francis and Hezel, 1974).

For other theorists, according to Francis and Hezel (1974), the primary place of education in development was more a matter of recognizing the value of capital investment in human beings. Little wonder that that Gunnar in Francis and Hezel (1974) reiterates that countries are underdeveloped because most of their people are underdeveloped, having had no opportunity of expanding their potential capital in the service of society.

Although the argument here is not on the level of education that brings about development; Tilak (2007) notes that basic education rarely serves as a meaningful level of education; and even if it imparts some valuable attribute, in terms of attitudes and skills, they are not sufficient. Although it helps reduce poverty, it only raises the poor just above the poverty line and leaves them in danger of falling below poverty line again.

No doubt literacy, basic and secondary education are very important in poverty reduction and development, the demand for highly skilled workers is increasing, especially in the context of globalization. This has a direct influence on the demand for higher education. Tilak (2007) reports that a recent analysis of Indian and cross-national data on higher education, economic growth and development using poverty and human indicators such as infant mortality and life expectancy, clearly shows that higher education plays a significant role in development. Through a regression analysis of inter-state data and a large cross-section of developing and developed countries, the analysis found a strong correlation between higher education and development. It was empirically shown that:

> Higher education enhances the earnings of individuals and contributes to economic development;

> Higher education makes a significant contribution to reduction in absolute as well as relative poverty;

$>$ Higher education is related to human development indicators which reflect other dimensions of human poverty, as it significantly reduces infant mortality and increases life expectancy.

It is often said that the difference between developed and developing nations are in the quality of their education. This implies that education has a significant relationship with development. Uwadia (2010) in agreement with this, maintains that the single most significant complex of socialcontrol tools for national development is found in the educational system be it formal or informal. In relating education to development, the centre for Global Development (2002) reports as follows:

- Education gives people the skills they need to help themselves out of poverty and into prosperity;

- With education, people are better prepared to prevent disease and to use health services effectively

- In many poor countries, with each additional year of schooling, people earn $10 \%$ higher wages. These earnings, in turn, contribute to national economic growth. 
- Education supports the growth of any society, democracy, and political stability, allowing people to learn about their rights and acquire the skills and knowledge necessary to exercise them.

Many of the developed countries are investing heavily in the education of her citizens. It is in line with this that the Federal Republic of Nigeria (2004) recognizes education as an instrument par excellence for national development. All the restructuring and policy formations in education are aimed at repositioning education for national development. The huge investment many international organizations and agencies like UNICEF, UNESCO, USAID and DFID, are making in education are in recognition of the role of education in development. The Millennium Development Goals (MDGs) are anchored on the premise that poverty reduction and the provision of basic social services should be at the core of development. In fact all the eight goals are linked to education and development.

\section{Business Education and National Development}

Business education has been defined in several ways, most of which highlight its vocational nature. It is a form of vocational education that is directed towards developing the learner to become productive in teaching, paid employment and self-employment (Idialu in Amoor, 2010). Business education prepares beneficiaries for gainful employment and sustainable livelihood. It is generally seen as education for and about business. Business education for business is that aspect of vocational education which provides instruction and preparation for office occupations such as secretary, shorthand-typist or stenographer, bookkeeper, data processor, word processor, computer analyst and accountant. On the other hand, education about business provides knowledge and understanding of the economic, financial, marketing, accounting, management system and other branches of business endeavour. In other words, education about business prepares students to function intelligently as consumers and citizens in a business economy.

Amoor (2010) notes that business education plays a significant role in the economic development by providing knowledge and skills to the learners, thereby, enabling them to adequately impart knowledge into others, and handle sophisticated office technologies and information systems. The goal of business education is primarily to produce competent, skillful and dynamic business teachers, office administrators and businessmen and women that will effectively compete in the world of work. It has as its primary aim, the preparation of people for roles in enterprises such roles could be as employee, entrepreneur and employer or simply as selfemployed.

Vocational and technical skills and competence has been identified (Rufia, 2013) as critical success factors in the actualization of Nigerian Vision 20:2020 which is about Nigeria becoming one of the first 20 economies in the world by the year 2020. Business education holds the prospect of contributing, through its job creation and self-employment packages, for the attainment of vision 20:2020. A gainfully employed individual contributes to GDP per capita, reduces poverty and unemployment which are some of the indices of development. A well trained business educator can successfully be engaged into the following areas:

$>$ Teaching profession from secondary to university level depending on qualification

$>$ Business enterprise - as a promoter, manager, marketer, account clerk, secretary, word processor, sales representative, broker etc.

$>$ Proprietorship of private schools - primary, secondary, tertiary, computer training institute and so on. 
There is no gain saying the fact that business education, an aspect of vocational education, is what Nigeria needs most now to help her solve most of her social, economic and developmental problems.

\section{Impediments to Quality Business Education}

Business education provides the knowledge, kills, attitudes and understanding needed to perform in the business world as a producer and or consumer of goods and services that business offers. It includes virtually all the knowledge which holds prospect for gainful employment. The realization of lofty aims of business education depends on how much the following challenges are tackled.

> Unqualified Teachers: Teachers are critical stakeholders in curriculum implementation. The employment of unqualified teachers to teach business courses is a great disservice to quality of business education graduates. It is a well known fact that most of the higher institutions that offer business education programme suffer from shortage of qualified teachers (Amoor in Ugwuogo, 2012). Business education has become a dumping ground sort of for graduates from different disciplines employed in the name of business educator.

> Obsolete Technologies: Manual typewriters are still largely in use. Some available morden ICTs are grossly inadequate.

$>$ Under Utilization of Computers: The department is not taking full advantage of shared printer, shared logic/resources and networking.

$>$ Large Class Size: The high teacher-student ratio affects quality of delivery of practical courses like word processing, data processing, shorthand and others.

> Poor Funding: Many administrators fail to understand that business education programme is capital intensive. It is a well known fact that one of the major problems bedeviling education in Nigeria today is inadequate funding and business education is no exception.

\section{Conclusion}

Education remains the foundation of human resources development required for national development. The above assertion is supported by studies which showed significant relationship between education and development. Vocational and technical education, which business education is part of, has been identified as a means of tackling poverty and unemployment. Business education has the potential of engendering development if the identified impediments are tackled headlong.

\section{Recommendations}

The following recommendations if implemented will help in increasing the capacity of business education to engender development:

1. Only qualified business educators should be recruited to teach business education courses at all educational levels. The already recruited ones should as a matter of urgency go for retraining especially in the use of ICTs.

2. Obsolete technologies should give way to computers and other modern ICTs. 
3. Computer laboratories should be properly networked for teachers and students to take full advantage of shared printer, shared logic/resources and other resources.

4. Teacher-student ratio of 1:30 should be maintained for quality delivery of practical courses.

5. Government and proprietors should increase funding of business education programme. Also, institutions and business education departments are urged to look for alternative means of funding to argument fund from government and proprietors.

\section{References}

Amoor, S.S. (2010). The need to improve teacher quality in business education in Nigerian universities. International J ournal of Education Research 11(1) 1-11

BusinessDictionary.com (2010). What is education? Definition and meaning. Retrieved $16^{\text {th }}$ April from http://www. businessdictionary.com/definition/ education.htm

Center for Global Development (2002). Education and the developing world. Retrieved April 3, 2013 from www.econ. lastate.edu/ cordoba/red.pdf

Development Workers in Global Solidarity (2010). What is development? Retrieved April 29, 2013 From http://www.volunteerinoptions.org/VolunteeringDevelopment/whatisdevelopment

Federal Republic of Nigeria (2004). National Policy on Education. Lagos: NERDC Press

Francis, X. and Hezel, S.J . (1974). Recent theories of the relationship between education and development. Retrieved April 16, 2013 from http://micsem.org/articles/education/rectheor.htm

Parankimalil, J. (2012). Meaning, nature and aims of education. Retrieved April 16, 2013 from http://johnparankimalil.wordpress.com/2012/03/26/meaning- nature-aid-aims-of-education

Rufai, R.A. (2013). Nigeria's attainment of vision 20:2020 depends on massive vocational and technical skills. Federal Ministry of Education Weekly Bulletin 2(58). March 26.

Tilak, J.B.G. (2007). Higher education, poverty and development. International Institute for Educational Planning Newsletter xxv(i) January - March 2007.

Ugwuogo, C.C. (2012). Global competitiveness and quality assurance in business education in Nigeria. A paper presented at the $24^{\text {th }}$ Annual National Conference of Association of Business Educators of Nigeria (ABEN) held at Federal Polytechnic, Nekede, Owerri from $16^{\text {th }}-20^{\text {th }}$ October.

UNESCO (2009). Education and national development in Nigeria. Retrieved April 16, 2013 from http://community.vanguardngr.com/profiles/blogs/education-and-national-development-in-Nigeria

$\begin{aligned} & \text { Wikipedia (2012). } \\ & \text { http://en.wikipedia.org/../Econnomy_of_Nigeria }\end{aligned}$
Economy of Nigeria. Retrieve April16, 2013 from

